\title{
Why Is the Research on Higher Education and Labor Market Nexus Needed in Transitional Bangladesh?
}

\author{
A. N. M. Zakir Hossain ${ }^{1,2^{*}}{ }^{\circ}$, Mosa Shrabony Sheikh ${ }^{3}$ \\ ${ }^{1}$ Faculty of Public Governance and International Studies, National University of Public Service, Budapest, Hungary \\ ${ }^{2}$ Department of Agricultural Economics, Bangladesh Agricultural University, Mymensingh, Bangladesh \\ ${ }^{3}$ Faculty of International Management and Business, Budapest Business School University of Applied Sciences, Budapest, \\ Hungary \\ Email: *anmzakirhossain@bau.edu.bd, shrabonybau@gmail.com
}

How to cite this paper: Zakir Hossain, A. N. M., \& Sheikh, M. S. (2021). Why Is the Research on Higher Education and Labor Market Nexus Needed in Transitional Bangladesh? Journal of Human Resource and Sustainability Studies, 9, 304-316. https://doi.org/10.4236/jhrss.2021.92019

Received: April 23, 2021

Accepted: June 5, 2021

Published: June 8, 2021

\section{Copyright $\odot 2021$ by author(s) and} Scientific Research Publishing Inc. This work is licensed under the Creative Commons Attribution International License (CC BY 4.0).

http://creativecommons.org/licenses/by/4.0/

Open Access

\begin{abstract}
Inequality is growing all over the world. As literature shows, two determinants are repeatedly mentioned, responsible for this inequality: incomes and jobs. The growing international trade and technological advancement direct this change as machines are increasingly replacing jobs. Nowadays, Bangladesh is gaining progress in transforming the rural-based agrarian economy approaching modern urban-based manufacturing and service-based economy, contributing a sound basis for further transformation. Simultaneously, it was an agricultural country from its genesis, and agriculture played a dominant role in the economy regarding income generation and employment opportunities. Education is pertinent in this regard as it has significant implications in human capital and the labor market. This study strives to identify the influence of governance in higher education and the labor market and focuses on exploring the significant determining factors of inequality in the existing society. It also tries to answer why the research on higher education and the labor market is essential in Bangladesh for self-sustaining and how the research could be executed. In this global era, institutions produce a bias in favor of the status quo. This study focuses on knowing how this bias will change through research on governance in education and the labor market in the future. Finally, the study concludes by expecting the practical outcomes of further research on higher education and the labor market for sustainable growth and development.
\end{abstract}

\section{Keywords}

Higher Education, Labor Market, Inequality, Bangladesh 


\section{Introduction and Background of the Study}

Bangladesh is a developing country that resided in south Asia, sharing a border with India and Myanmar, emerged as a sovereign state after a nine-month-long bloody war of liberation in 1971 against Pakistan. However, Bangladesh has appreciably managed to thrive through thick and thin. It indeed has to continuously confront the debilitating impacts of acutely adverse land-man ratio, poor natural resource base, lousy governance, frequent attacks from natural hazards, and the curse of climate change. Despite all of the odd over the head, Bangladesh has so far depicted several developments on different fronts, notwithstanding the question of sustaining them. The emerging belief seems to be that the resilience of Bangladesh has gradually improved concerning per capita income, food security, infant and maternal mortality, disaster management, micro-credit programs, and income and non-income poverty. So it is evident that Bangladesh has so far portrayed exhilarating commendable progress concerning some socio-economic indicators. However still, the country faces a plethora of difficulties and problems associated with governance. However, the point is that things could have been much better if government and politics could play their productive role. Bangladesh, from its genesis, was primarily an agricultural country. Agriculture played a dominant role in the economy regarding income generation and employment opportunities for the vast rural populace. However, Bangladesh nowadays is gaining progress in transforming the rural-based agrarian economy approaching modern urban-based manufacturing and service-based economy, which contributes a sound basis for further transformation. Bangladesh is now tending to a middle-income country but still recognized as the developing country of the world for many reasons, i.e., illiteracy, poverty, corruption, instability in politics, and many more. Education is a powerful tool, among others, that can lead to overcoming these numerous impediments and overtake the country approaching sustainable development. Though, Bangladesh has gained remarkable success in the education sector regarding primary enrollment, rising female students at various levels, improving the passing rate in different public examinations, scholarship for female students, free textbooks, and establishing the new educational institution.

Despite such progress, the drop-out at the primary level is still shocking. At the same time, the connection between education and the labor market becomes a perennial topic in the economics of education (Psacharopoulos, 1986). The quality of higher education and economic growth is very intimate in any country that proved by the research and studies on several parts of the world. In contrast, the quality of education is an evolving concern in developing countries (Hanushek et al., 2011; Hanushek, 2013; Kaarsen, 2014; Schoellman, 2012; Manuelli \& Seshadri, 2014; Boccanfuso et al., 2015). Because the quality of the higher education sector and the educational attainment are associated more closely, and it can contribute to the inclusive development of any country (Bacolod and Tobias, 2006; Barro and Lee, 2013). The education quality of Bangladesh is criticized at 
all levels, particularly at the tertiary level, due to its augmentations and implications in contribution to the human capital and labor force of the country to equip it to face the challenges of globalization and attain sustainable development goals. In addition, the influence of tertiary level education profoundly impacts individual earnings when the education and quality of the higher education sector have ignored in the developing world, like other developing countries, research on economic and policy studies unnoticed to design for the future policies in Bangladesh (Monem and Muhammad, 2010; Kimenyi, 2011; Barro and Lee, 2013). Shockingly, the research of educational quality in developing states focuses on the primary and secondary level only for the effects on the outcomes from education however the quality of education alone is misleading (Bacolod \& Tobias, 2006; Hanushek \& Woessmann, 2008; Behrman and Birdsall, 1983; Behrman et al., 2008). The annual change in the growth rate of the labor force in Bangladesh is increasing combines the women in the mainstream labor force, which has a significant contribution to the national income as a whole, shown in Figure 1. However, the substantial numbers of unskilled labor in the labor force added a burden due to skill mismatches and suffering from it to fix it in an economy (Pauw et al., 2008) that could contribute to economic growth when improving the quality of higher education lead to higher income and employment rates (Ordine \& Rose, 2011). The dynamic demand of labor and the equilibrium models of the labor market have been systematically investigated the flexibility of the labor market at different times due to the effect of decreasing employment scope in any labor market (Turnham and Jaeger, 1971; Boeri \& Garibaldi, 2019; Bentolila \& Bertola, 1990; Garibaldi, 1998; Millard \& Mortensen, 1997; Nickell, 1986; Boeri \& Van Ours, 2013). Yet, many of the unskilled labor migrated to the Arab countries and contributing to the national economy in every critical situation through their remittance, but studies urge for migration governance for effective management of migrants for economic sustainability (Siddiqui, 2016).

To support this, the government of developing countries has to work to minimize the gap between the skill and the growing demand for labor force worldwide

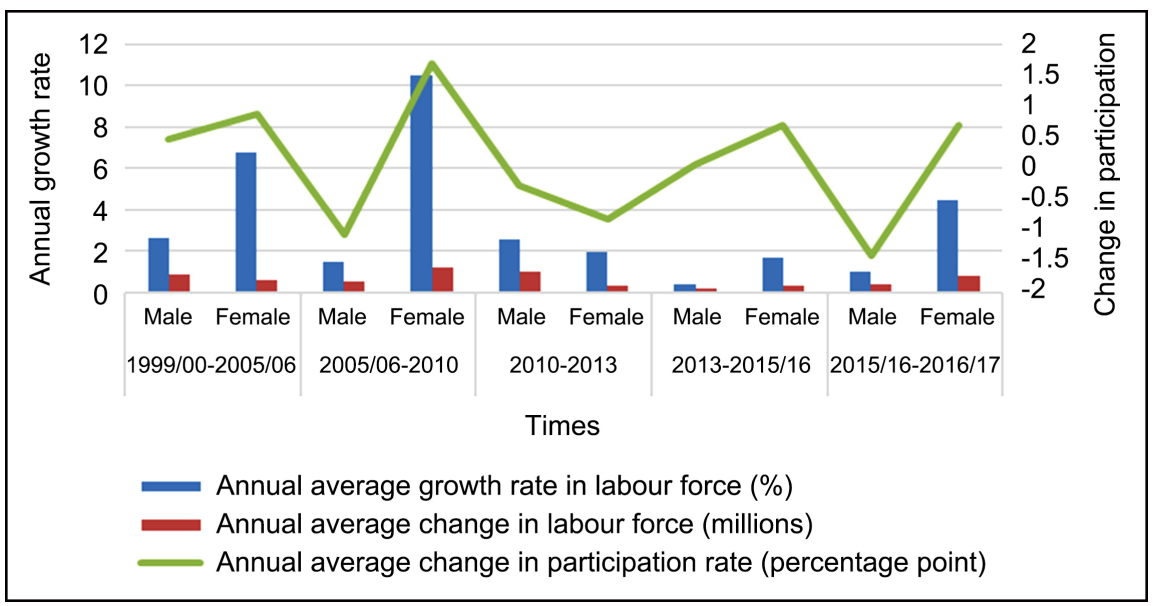

Figure 1. Annual average change in the labor force participation (BBS, 2017; LFS, 2017). 
wide. Skill mismatch is a rising concern of current debate among policymakersdue to its repercussion on an economy at a different level (Lauder and Mayhew, 2020). At a personal level, it influences the wage and job satisfaction, and at the farm level, it affects the production sector that ultimately damages the equilibrium unemployment and decreases GDP growth through the loss of human capital and the decline of productivity it generates. But in Bangladesh, this is not happening; why and how in Bangladesh this notion is acting differently? Under which conditions and to what extent the political system can do this. It is essential to discover the causes of skill mismatch and design an inclusive policy, including education quality and higher education policy, to mitigate the situation. It is indispensable to the restoration of higher education for sustainable, comprehensive development in this 21 st century. It entirely equips society to meet the challenges and become intellectually sovereign because without advanced knowledge of science, progressive citizens, and competent specialists, it may not be possible. It is needless to emphasize that their absence of the country is bound to be inefficient. Unemployment is the most striking symptom of inadequate development in most third world countries of the world. Now, a high percentage $(61.1 \%)$ of youth and working-age groups implies a demographic dividend for Bangladesh.

Every year 20 lacs new labor force is being added. According to the 2015 labor force survey report, the number of unemployed persons is 25 lacs 90 thousand among the working labor force. Besides this, 23 lacs are partially employed. Altogether the number of total unemployed persons in the country is about 49 lacs (Prothom Alo 1 May 2016 and LFS, 2017). Again, among the educated unemployed, the Honours and Master degree holders are the highest. According to the 2013 Labour Force Survey rate of unemployment of SSC passed persons 7\%, HSC passed 13.6\%, Degree and Master Degree holders 16.4\%. During the four years from 2013, the growth rate has increased, but the employment opportunities have not increased to that extent. For that reason, some Economist says this type of development is "growth without employment" (Prothom Alo 8 August 2017, LFS, 2017). The current study will focus on the higher education sector, especially the tertiary level shown in Figure 2. There are many pitfalls in this sector that owe the management of offices at this level, including variation regarding the working days and hours, statutory meetings not held routinely. Also, the study will examine the strength and weakness of the education governance of Bangladesh, analyzing the structure and growth of human capital and labor force and its trends towards employment to arrive at specific inferences in the changing competitive environment during this transition.

The article is structured as follows. First, we describe the background and the problem statement relating to the importance of research on higher education and the labor market in Bangladesh. Then we explain the conceptual and analytical framework for analyzing the research on higher education and labor market nexus in Bangladesh. After that, we go for the theoretical model, which can be a building block for the research on the higher education and labor market policy for further research that can contribute to future policy guidelines (Schöb, 2016). 


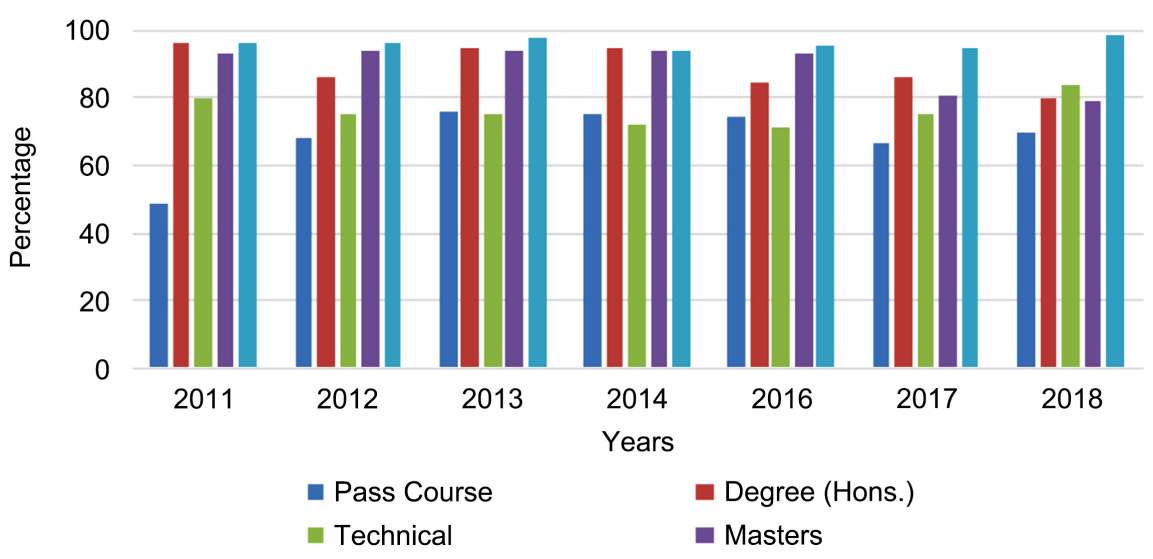

Figure 2. Output statistics of examinations conducted by public universities (2011-2018). Source: http://data.banbeis.gov.bd.

Then, we present the research methodology for the scientific studies on higher education connected to the labor market, which the researchers can follow to study the issues. In conclusion, we have highlighted the research outcome on higher education and the labor market policies and their utility to help the students, researchers, and policy makers for further utilization of the research findings.

\section{Conceptual and Analytical Framework}

Empirical research requires a conceptual framework. The conceptual framework of research on education and the labor market in Figure 3, will test the implication of higher education and human capital and their impact on the labor market at the national level. The conceptual framework of these studies depicts the process of higher education governance and its effects to achieve the desired human capital formation to meet the demand of the labor market.

The conceptual framework can be developed using key elements (variables) of higher education from existing literature. It attempts to show how the independent variables might have occurred changes on dependent variables because inputs required achieving the desired outcomes. Moreover, it will allow the development of interview questions by linking each question return to the framework with consideration given to triangulation of the data collected to answer the research question and aid to review the studies on education and labor market.

The analytical framework is helpful for in-depth analysis consistent with the conceptual framework of the research studies on higher education and the lobar market. It can be applied for the performance model from the benchmarking stand indicating the performance of the existing systems that could be helpful to revitalize the excellent labor market outcomes for the job seekers. By this analytical framework, in Figure 4, one can investigate through the in-depth analysis at "public policies influence activities within higher education in ways that support the labor market relevance and outcomes of the systems (OECD, 2017)". It can be helpful to evaluate the efficiency of government policies and practices through computing outputs (graduates of higher education) and outcomes (la- 
bor market outcomes). Through this process, the model will offer a solid foundation for understanding the causes after higher education performances. This model also provides to ponder which factors should be measured to investigate during the research. Finally, it will allow developing evidence-based strategic guidance to states on "how they can improve the labor market relevance and outcomes of their higher education systems (OECD, 2017)".
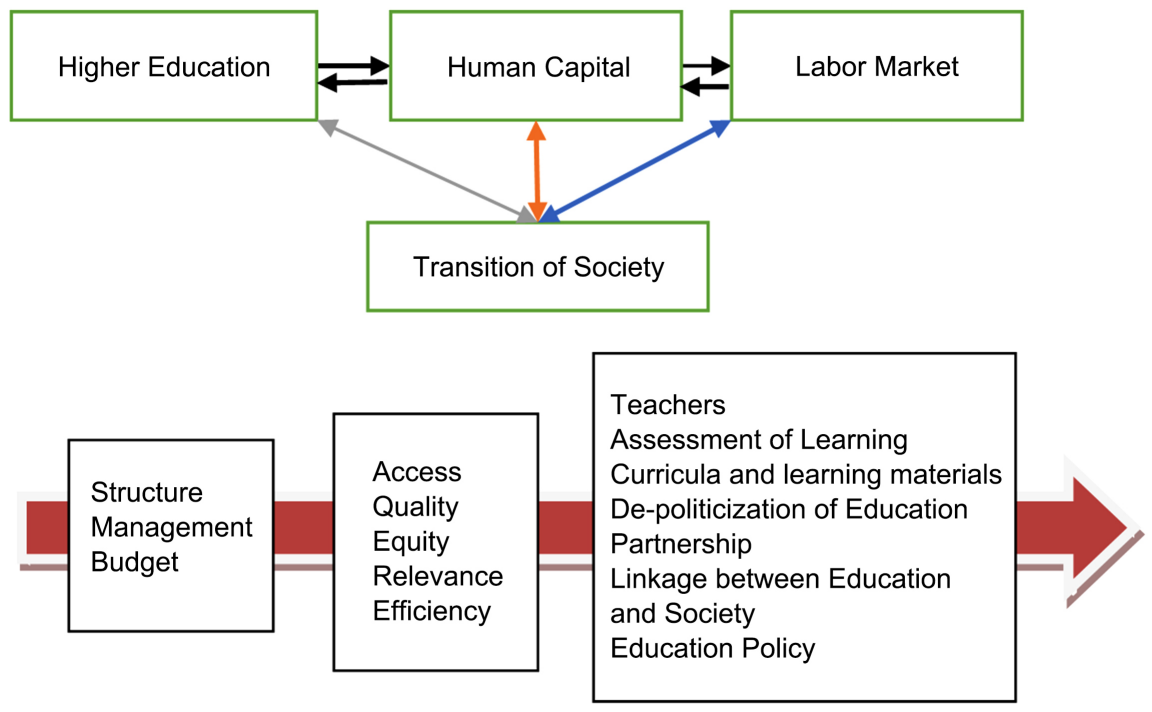

Figure 3. Conceptual framework.

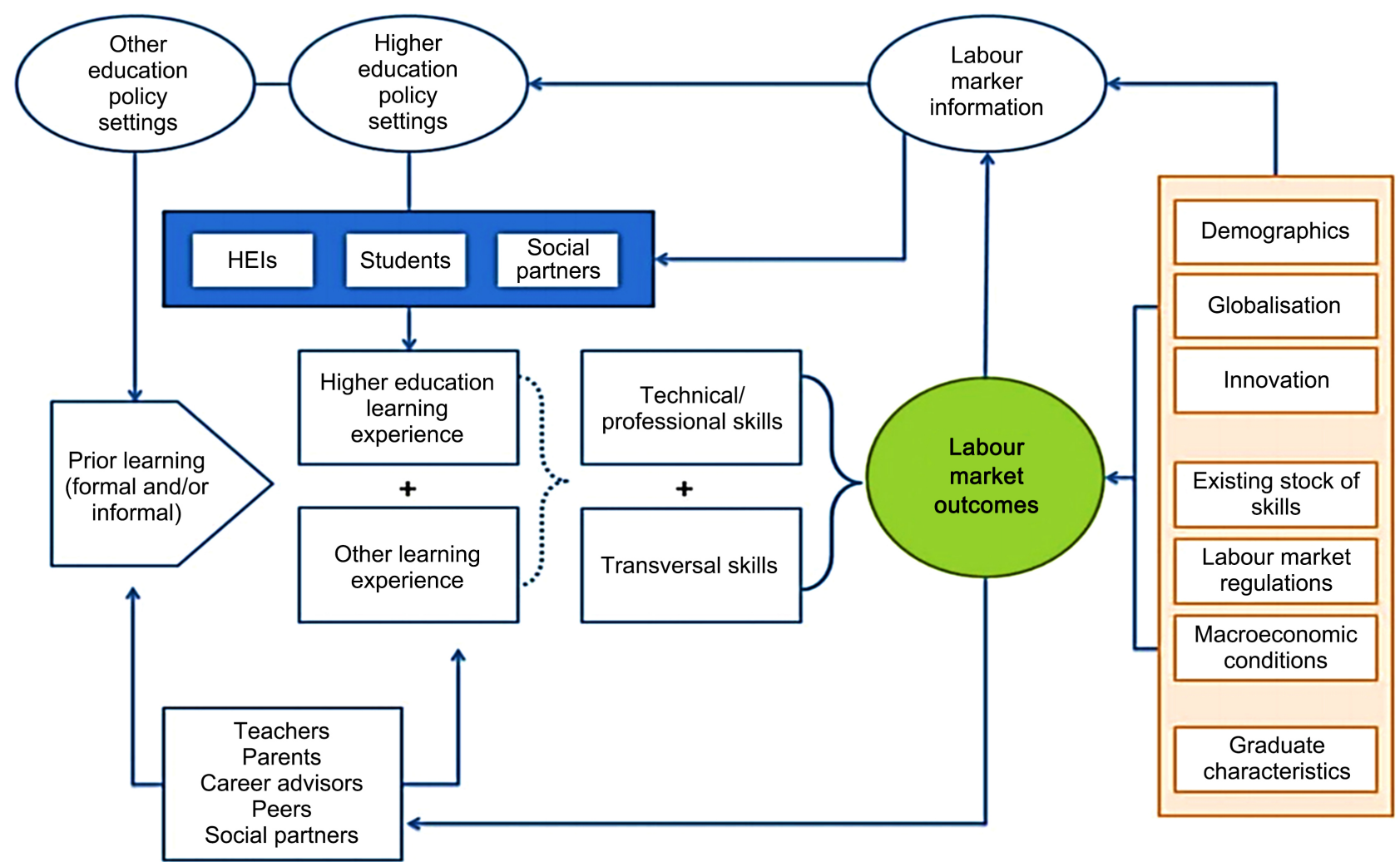

Figure 4. Analytical framework of the labor market and outcomes of higher education (Source: OECD, 2017). 


\section{Which Research Questions and Objectives Can Be Focused on during Research on Education and Labor Market Nexus?}

The studies on higher education and the labor market can be conducted based on the following research questions: How does governance influence the quality of education? What is the nature of governance problems in the education sector that confront quality education in Bangladesh? Under which conditions and mechanisms triggered the changes in human capital and labor markets. What are the causes of employment problems in Bangladesh, and how these problems lead to an analysis that engages the whole socio-economic structure and touches on almost every element of the development strategy? How and to what extent education contributes to human capital? How globalization contributes to the labor market and creates inequality in/within the societies? What are the determinant factors that lead to this inequality? What are the causes of skill mismatch? How to manage the demands and challenges that coming near future? Does a gender dimension issue work during employment how and why? What are the nature and dimensions of unemployment, and how affect the more substantial part of the labor force and do open employment in the developed countries/worlds?

Based on the following research questions, the studies on higher education and the labor market focus on providing an overview of the governance of higher education and demographic structures with significant emphasis on human capital and labor market trends in Bangladesh. The study will further evolve around the university quality and relationship of other factors and the effect of the university on social mobility and human capital development. Furthermore, we can focus on covering the aspects of the economics of higher education. Specific objectives are:

- to explore the governance challenges of higher educational institutions.

- to identify the factors and actors that hamper the quality of education at this level.

- to classify the determinants of pupils academic performance for future career.

- to examine the structural characteristics of unemployment.

- to identify the impact of globalization on social inequality and the consequences on the labor market.

- to the features of the labor force and the structure of employment at the national and international levels.

\section{Possible Theoretical Framework for Researching Higher Education and Labor Market}

\subsection{Theory of Governance}

Governance is nowadays getting tremendous importance in social, economic, and political phenomena. Max Weber and Woodrow Wilson contributed a lot to the modern public administration landscape; without their contribution, the 
field of governance would be unrecognized. The functional uniformity, comprehensiveness, hierarchy in the organization, and strong leadership that democratically responsible and recruited impartially competent civil servants who provide services to the people, to the level they still existed. This process has replaced and offers many essential services by multi-organizational programs by an "organizational society". Which are fundamentally "interconnected clusters of firms, governments, and associations which come together within the framework of these programs" (Hjern and Porter, 1981), and this notion of governance has gained a surprising level of consensus. There is a ubiquitous, shared, universal perception of governance as a subject far broader than "government"; the governance approach is seen as a "new process of governing, or a changed condition of the ordered rule; or the new method by which society is governed" (Stoker, 1998). In this compound, a devolved form of service delivery, the item of analysis for some students of policy implementation is the complex of private firms, nonprofit organizations, and governments. As Milward and Provan (2000) note, “...joint production and having several degrees of separation between the source and the user of government funds... combine to ensure that hierarchies and markets will not work and that networks are the only alternative for collective action". Although the term "governance" entered in the intellectual discourses in the last decades of the 20th century in the global arena now, its reforms are externally driven which has a long intellectual history. Today governance has come to signify political liberalization and market reforms on the lower scale and democratic development on the upper scale.

"Governance refers to the development of governing styles in which boundaries between and within public and private sectors have become blurred. The essence of governance is its focus on mechanisms that do not rest on recourse to the authority and sanctions of government... (Bekke et al., 1995; Peters and Pierre, 1998; Stoker, 1998; Rhodes, 1996, 1997). Governance for (some) is about the potential for contracting, franchising, and new forms of regulation. In short, it is about what (some) refer to as the new public management. However, governance... is more than a new set of managerial tools. It is also about more than achieving greater efficiency in the production of public services (Stoker, 1998)."

\subsection{Human Capital Models}

Schultz (1961) explored the idea of "human capital" investment in human beings. Interestingly, the importance of human capital (the late 1940s) came to him as he realized that models of economic growth did not explain differences in per capita income (across countries). Traditional Human Capital Theory undermines the theoretical value of education. Neoclassical economic orthodoxy has continued a long ritual of opposition based on that it is founded on a cosmology that is not easily recognizable in the real world (Rothschild, 2002). As a creation of neoclassical economics, human capital theory inherits its metaphysical as- 
sumptions of the "hardcore" of the orthodox economics research program (Zamora, 2006). The contemporary view (following Marshall) of labor was a homogenous lump; only the amount mattered. Marshall recognized investment opportunities to increase skills and capabilities while this property is in people another form of capital, human capital. It has the significance that the capital is involved in the person. Thus, the owner of capital cares about working conditions, schooling, training programs, experience (on-the-job training), health, migration-and investment to leave a poor and move to a good labor market. Pay fixed cost today for higher wages, earnings "tomorrow". Pre-market and pre-schooling investments by parents (e.g., child care, Head Start) and "Early life investments" all the rage today. Human capital is intentionally accumulated, not just the outcome of population growth (which is zero) or exogenously specified technological progress. According to Blaug (1947), education in human capital theory produces a net positive marginal product that is only tested in difficulty, that is to say, under improbable conditions. This is partial as it involves "leaps of logic" to allocate marginal product owing to education to labor, as different from other factors, while also needlessly assuming that marginal product can be matched to individuals. Besides, the notion higher earnings of more-educated workers imply their superior marginal product relative to less-educated workers ironically founders on the neoclassical assumption of labor market competition. So it is only the case of perfect labor market competition; even in the improbable situation of competitive labor markets, Blaug states that there is a lack of predictive power in the competitive labor market, and it fails to indicate the time frame where to produce an answer in disequilibrium situations. The net effect of these insufficiencies is that one is induced to consider the notion that higher education makes people higher productive, as evidenced in their higher earnings as merely an assumption whose precision, in turn, depends on still other assumptions.

\section{What Research Methodology Can Be Practical?}

The methodological approaches are crucial for any research to keep the research on the right track to reach the research objectives and solve the problem we intended to crack through the study. The researchers and academicians widely acknowledge that the research in social science has been driven by challenges, not driven by methodology, where the methods are the way to approach the problems and seek answers. The challenges that researchers are willing to encounter through their studies will suggest several approaches that fit the study based on the problem statements and the objectives to get the scientific and valid answers for the research questions. It will pave the way for scientific research to follow a correct route that can suggest practical solutions to the problems.

The research on education and the labor market can be a cross-sectional study. Both qualitative and quantitative methods can be helpful to achieve the objectives of the study. The triangulation design can also be beneficial because the strength of the qualitative and quantitative approach enriches the research 
credibility and ensures a more valid result. Also, the researchers analyze the relevant policies for the importance of the education system. The studies can follow a quantitative research design to obtain causal effects of both environmental factors and university-specific determinants of educational attainment and students transition into the labor market. For this, time-series data and panel data (depends on availability) will be helpful for further inferences. The estimation from panel data for cross-sectional analysis yields various advantages for investigating the effect of job mismatch over time (Johnes and Johnes, 2019). However, it produces some doubts on the results of the cross-sectional analyses that control the literature. The study on Australian panel data identified that unobserved individual differences play an influential role in defining the association between job mismatch and labor market outcome. However, a single country data with a single group of graduates offers room for manifestation to the data that is not representative (Sloane, 2020; Mavromaras et al., 2013a; Mavromaras et al., 2013b). In this study, we can suggest the researchers collect data from both primary and secondary sources. Focus Group Discussion (FGD) and Key Informant Interviews (KII) can be carried out with different stakeholders to refine and further elaborate on the data. To analyze data appropriate statistical method can be used, i.e., Ordinary Least Squares (OLS), Logistic Regression Technique, Binary logit model, etc., which will fit their models and objectives.

\section{Conclusion: What Can We Expect as Output?}

In this paper, we tried to explain why we focus on the collaborative and comprehensive research of higher education and the labor market in Bangladesh. The self-sustaining economic growth and development are essential for sustainable development in the $21^{\text {st }}$ century when Bangladesh is suffering from a thousand hundreds of unemployed graduates while scarcity of handsome amount of technical human resources. To move forward, holistic research and long-term planning are essential for future sustainability, which is reemphasized in this study. The studies on education and labor market nexus can identify the requirement of educational infrastructure and the contribution of education and other determinants of human capital in the demographic transition. The research outputs will be helpful for the students, researchers, and policymakers for their further usage. It can be beneficial for the policy makers for labor policy and other allied sciences, which can be mingled with the education governance and the labor market to accelerate economic growth and sustainability in the coming days. The studies on the said aspects will be helpful to the original allocation of the resources to govern the higher educational institutions to reshape the administrative process and contribute more to the labor market and enable the institutions for more inclusive decision-making and promote further transformation (Chevaillier, 2002).

\section{Conflicts of Interest}

The authors declare no conflicts of interest regarding the publication of this paper. 


\section{References}

Bacolod, M. P., \& Tobias, J. L. (2006). Schools, School Quality and Achievement Growth: Evidence from the Philippines. Economics of Education Review, 25, 619-632. https://doi.org/10.1016/j.econedurev.2005.08.004

Bangladesh Bureau of Statistics (BBS) (2017). Report of Labor Force Survey (2015-2016). Dhaka: GoB.

Barro, R. J., \& Lee, J. W. (2013). A New Data Set of Educational Attainment in the World, 1950-2010. Journal of Development Economics, 104, 184-198. https://doi.org/10.1016/j.jdeveco.2012.10.001

Behrman, J. R., \& Birdsall, N. (1983). The Quality of Schooling: Quantity Alone Is Misleading. American Economic Review, 73, 928-946.

Behrman, J. R., Ross, D., \& Sabot, R. (2008). Improving Quality versus Increasing the Quantity of Schooling: Estimates of Rates of Return from Rural Pakistan. Journal of Development Economics, 85, 94-104. https://doi.org/10.1016/j.jdeveco.2006.07.004

Bekke, H., Kickert, W., \& Kooiman, J. (1995). Public Management and Governance. In Kickert, \& F. A. van Vught (Eds.), Public Policy and Administrative Sciences in the Netherlands (pp. 201-218). London: Harvester-Wheatsheaf.

Bentolila, S., \& Bertola, G. (1990). Firing Costs and Labor Demand: How Bad Is Eurosclerosis? The Review of Economic Studies, 57, 381-402. https://doi.org/10.2307/2298020

Blaug, M. (1947). The Correlation between Education and Earnings: What Does It Signify? Higher Education Quarterly, 1, 53-76. https://doi.org/10.1111/j.1468-2273.1947.tb02069.x

Boccanfuso, D., Larouche, A., \& Trandafir, M. (2015). Quality of Higher Education and the Labor Market in Developing Countries: Evidence from an Education Reform in Senegal. World Development, 74, 412-424. https://doi.org/10.1016/j.worlddev.2015.05.007

Boeri, T., \& Garibaldi, P. (2019). A Tale of Comprehensive Labor Market Reforms: Evidence from the Italian Jobs Act. Labour Economics, 59, 33-48. https://doi.org/10.1016/j.labeco.2019.03.007

Boeri, T., \& Van Ours, J. (2013). The Economics of Imperfect Labor Markets. Princeton, NJ: Princeton University Press. https://doi.org/10.2307/j.ctt32bc18

Chevaillier, T. (2002). University Governance and Finance: The Impact of Changes in Resource Allocation on Decision Making Structures. In A. Amaral, G. A. Jones, \& B. Karseth (Eds.), Governing Higher Education: National Perspectives on Institutional Governance (pp. 87-98). Dordrecht: Springer. https://doi.org/10.1007/978-94-015-9946-7_5

Garibaldi, P. (1998). Job Flow Dynamics and Firing Restrictions. European Economic Review, 42, 245-275. https://doi.org/10.1016/S0014-2921(97)00062-7

Hanushek, E. A. (2013). Economic Growth in Developing Countries: The Role of Human Capital. Economics of Education Review, 37, 204-212. https://doi.org/10.1016/j.econedurev.2013.04.005

Hanushek, E. A., \& Woessmann, L. (2008). The Role of Cognitive Skills in Economic Development. Journal of Economic Literature, 46, 607-668. https://doi.org/10.1257/jel.46.3.607

Hanushek, E. A., Woessmann, L., \& Zhang, L. (2011). General Education, Vocational Education, and Labor-Market Outcomes over the Life-Cycle (No. w17504). Cambridge, MA: National Bureau of Economic Research. https://doi.org/10.3386/w17504 
Hjern, B., \& Porter, D. O. (1981). Implementation Structures: A New Unit of Administrative Analysis. Organization Studies, 2, 211-227. https://doi.org/10.1177/017084068100200301

Johnes, G., \& Johnes, J. (2019). Panel Data in Educational Research. In Panel Data Econometrics (pp. 467-493). Academic Press. https://doi.org/10.1016/B978-0-12-815859-3.00014-7

Kaarsen, N. (2014). Cross-Country Differences in the Quality of Schooling. Journal of Development Economics, 107, 215-224. https://doi.org/10.1016/j.jdeveco.2013.11.005

Kimenyi, M. S. (2011). Contribution of Higher Education to Economic Development: A Survey of International Evidence. Journal of African Economies, 20, iii14-iii49. https://doi.org/10.1093/jae/ejr018

Lauder, H., \& Mayhew, K. (2020). Higher Education and the Labour Market: An Introduction. Oxford Review of Education, 46, 1-9. https://doi.org/10.1080/03054985.2019.1699714

LFS (2017). Bangladesh Bureau of Statistics, Ministry of Planning, Government of the People's Republic of Bangladesh.

Manuelli, R. E., \& Seshadri, A. (2014). Human Capital and the Wealth of Nations. American Economic Review, 104, 2736-2762. https://doi.org/10.1257/aer.104.9.2736

Mavromaras, K., Mahuteau, S., Sloane, P., \& Wei, Z. (2013b). The Effect of Overskilling Dynamics on Wages. Education Economics, 21, 281-303. https://doi.org/10.1080/09645292.2013.797382

Mavromaras, K., McGuinness, S., O’Leary, N., Sloane, P., \& Wei, Z. (2013a). Job Mismatches and Labour Market Outcomes: Panel Evidence on University Graduates. Economic Record, 89, 382-395. https://doi.org/10.1111/1475-4932.12054

Millard, S. P., \& Mortensen, D. T. (1997). The Unemployment and Welfare Effects of Labour Market Policy: A Comparison of the USA and the UK. In Unemployment Policy: Government Options for the Labour Market (pp. 545-572). Cambridge: Cambridge University Press. https://doi.org/10.1017/CBO9780511752025.041

Milward and Provan (2000). Eastern Regional Organization for Public Administration (EROPA), From Government to Governance, Reflections on the 1999 World Conferences on Governance.

Monem, M., \& Muhammad, H. (2010). Higher Education in Bangladesh: Status, Issues and Prospects. Pakistan Journal of Social Sciences (PJSS), 30, 293-305.

Nickell, S. J. (1986). Dynamic Models of Labour Demand. Handbook of Labor Economics, 1, 473-522. https://doi.org/10.1016/S1573-4463(86)01012-X

OECD (2017). In-Depth Analysis of the Labor Market Relevance and Outcomes of Higher Education Systems: Analytical Framework and Country Practices Report, Enhancing Higher Education System Performance. Paris: OECD.

Ordine, P., \& Rose, G. (2011). Inefficient Self-Selection into Education and Wage Inequality. Economics of Education Review, 30, 582-597. https://doi.org/10.1016/j.econedurev.2011.03.007

Pauw, K., Oosthuizen, M., \& van der Westhuizen, C. (2008). Graduate Unemployment in the Face of Skills Shortages: A Labour Market Paradox. South African Journal of Economics, 76, 45-57. https://doi.org/10.1111/j.1813-6982.2008.00152.x

Peters, B. G., \& Pierre, J. (1998). Governance without Government? Rethinking Public Administration. Journal of Public Administration Research and Theory, 8, 223-243. https://doi.org/10.1093/oxfordjournals.jpart.a024379

Psacharopoulos, G. (1986). Links between Education and the Labour Market: A Broader 
Perspective. European Journal of Education, 21, 409-415.

https://doi.org/10.2307/1502684

Rhodes, R. (1996). The New Governance: Governing without Government. Political Studies, 44, 652-657. https://doi.org/10.1111/j.1467-9248.1996.tb01747.x

Rhodes, R. (1997). Understanding Governance: Policy Networks, Governance, Reflexivity and Accountability. Buckingham: Open University Press.

Rothschild, K. W. (2002). The Absence of Power in Contemporary Economic Theory. Journal of Socio-Economics, 31, 433-442. https://doi.org/10.1016/S1053-5357(02)00207-X

Schöb, R. (2016). Labor Market Policies, Unemployment, and Identity. IZA World of Labor. https://doi.org/10.15185/izawol.270

Schoellman, T. (2012). Education Quality and Development Accounting. The Review of Economic Studies, 79, 388-417. https://doi.org/10.1093/restud/rdr025

Schultz, T. W. (1961). Investment in Human Capital. The American Economic Review, 1, $1-17$.

Siddiqui, T. (2016). International Labour Migration. The Daily Star (25th Anniversary Special Part-5), 5 February 2016.

Sloane, P. J. M. (2020). Overeducation, Skill Mismatches, and Labor Market Outcomes for College Graduates. IZA World of Labor.

Stoker, G. (1998). Governance as Theory: Five Propositions. International Social Science Journal, 50, 17-28. https://doi.org/10.1111/1468-2451.00106

Turnham, D., \& Jaeger, I. (1971). The Employment Problem in Less Developed Countries: A Review, Chapter 3. Paris: OECD.

Zamora, B. (2006). A New Discussion of the Human Capital Theory in the Methodology of Scientific Research Programmes. The International Symposium on Economic Theory, Policy, and Applications, Athens, 21-23 August 2006, 19 p. 